\title{
PENGEMBANGAN BUKU CERITA ANAK BERGAMBAR DENGAN INSERSI BUDAYA LOKAL BALI TERHADAP MINAT BACA DAN SIKAP SISWA KELAS V SD KURIKULUM 2013
}

\author{
I Md. Aditya Dharma \\ Program Studi Pendidikan Dasar, Sekolah Tinggi Keguruan dan IImu Pendidikan Jembrana \\ Jembrana, Indonesia \\ email : adityadharma34@yahoo.com
}

\begin{abstract}
ABSTRAK
Penelitian ini bertujuan: 1) mengembangkan buku cerita anak berdasarkan muatan sikap dan muatan pembelajaran pada subtema Manusia dan Lingkungan kurikulum 2013, dengan menginsersi budaya lokal Bali yang relevan; serta 2) untuk mengetahui efektivitas buku cerita yang dihasilkan tersebut sebagai pendamping buku pelajaran K-13 dalam pembelajaran. Penelitian ini mengembangkan prototipe tersebut melalui tiga tahapan yaitu Development, Implementatian, dan Evaluation. Subjek pada penelitian ini adalah 2 orang ahli, 2 orang guru kelas $V$ dan 26 orang siswa kelas V Sekolah Dasar. Data dikumpulkan menggunakan kuesioner untuk minat baca dan sikap. Data dianalisis secara deskriptif kualitatif.Hasil penelitian menunjukkan bahwa, Hasil penelitian menunjukkan bahwa, (1) buku cerita berjudul "Pesona Pantaiku Pantai Lovina" memuat sikap spiritual, sikap sosial, dan muatan pembelajaran PPKn, Bahasa Indonesia, IPA, IPS, dan SBdP serta terdapat budaya lokal yang mendukung seperti kewajiban bersembahyang Mebanten Canang, mengucapkan salam Om Swastyastu, permainan tradisional Mecongklak dan bernyanyi Made Cenik. Berdasarkan hasil penilaian para ahli, diperoleh kualitas dan kesesuaian buku cerita "Pesona Pantaiku Pantai Lovina" tergolong sangat baik. (2) Melalui uji coba, diperoleh efektivitas penggunaan buku cerita "Pesona Pantaiku Pantai Lovina" terhadap sikap siswa sebesar 8,13 tergolong sangat efektif; terhadap minat baca siswa sebesar 5,33 tergolong sangat efektif; dan terhadap hasil belajar siswa sebesar 2,69 tergolong sangat efektif.
\end{abstract}

Kata kunci: budaya lokal Bali, buku cerita, sikap, minat baca

\begin{abstract}
This research aims at: 1) developed a children's book based on the payload attitude and loads of learning on subtema thematic study humans and the environment, with the mengaksentuasi local culture of Bali is relevant; as well as 2) to find out the effectiveness of the resulting story books such as the textbook companion K-13 in learning. This research developed the prototype through three phases namely Implementatian, Development, and Evaluation. On the subject of the research is 2 persons 2 persons expert master class $V$ and class $V$ students 26 elementary schools. Data were collected using a questionnaire for an interest read and attitude. The data analyzed in qualitative descriptive. The results showed that, the results showed that, (1) story book entitled "the charm my beach Lovina Beach" contains the spiritual attitudes, social attitudes, and loads of learning PPKn, Indonesian Language, NATURAL SCIENCE, SOCIAL SCIENCE, and there are cultural as well as SBdP local support as obligation of fire Mebanten Cymbals, mouthing greetings Om Swastyastu, Mecongklak and traditional singing games Made Cenik. Based on the results of the assessment of experts, obtained the quality and suitability of the story book "Charm Pantaiku Lovina Beach" belongs to very good. (2) through the trials, obtained the effectiveness of use of story book "Charm my beach Lovina Beach" against the attitude of students of 8.13 belongs to very effective; against the interest of students read 5.33 belongs to very effective; and against the results of student learning of 2.69 belongs is very effective.
\end{abstract}

Keywords: Bali local culture, story book, attitude,reading interest 


\section{Pendahuluan}

Pembelajaran tematik integratif merupakan pendekatan pembelajaran yang mengintegrasikan berbagai kompetensi dari berbagai mata pelajaran ke dalam berbagai tema. Pengintegrasian terwujud dalam dua hal, yakni: (1) integrasi sikap, keterampilan, dan pengetahuan dalam proses pembelajaran; dan (2) integrasi berbagai konsep dasar yang terkait. Tema merajut makna berbagai konsep dasar sehingga peserta didik tidak belajar konsep dasar secara parsial. Dengan demikian pembelajarannya memberikan makna yang utuh kepada peserta didik seperti tercermin pada berbagai tema yang tersedia (Hidayah, 2015).

Pembelajaran bermakna akan tercipta apabila anak SD mampu mengembangkan kemampuan berpikir naratif, dan memiliki rasa ingin tahu yang tinggi. Salah satu kegiatan yang anak-anak senangi adalah mendengarkan berbagai cerita atau dongeng. Menurut Piaget (dalam Marhaeni, 2013), anak usia SD yakni 6-12 tahun berada pada tahap operasional konkrit. Pada tahap ini anak dapat membuat pemikiran tentang situasi atau hal konkrit secara logis. Maka dari itu, karakteristik belajar anak pada tahap ini adalah belajar melalui hal-hal yang bersifat nyata dan menghindari cara belajar menghayal atau mengira-ngira. Namun, beberapa buku yang di temukan di lapangan tampak masih ada yang tidak menghadirkan situasi konkrit/nyata ke dalam pembelajaran. Sehingga muncul anggapan bahwa buku-buku tersebut tidak sepenuhnya relevan dengan karakteristik belajar anak usia SD. Mendengarkan dongeng sangat diminati oleh anak-anak yang berimbas secara langsung pada diri sendiri.

Bercerita mengandung unsur teladan yang bisa diberikan pada anak melalui ceritanya. Orangtua pasti menginginkan anak memiliki sikap dan prilaku moral yang baik. Moral yang positif pada anak tidak mungkin dengan memberikan ceramah dan memarahi jika anak atas kesalahannya. bercerita adalah menjadi salah satu metode yang disukai anak. Orangtua dapat memberikan cerita yang mengandung unsur moral dan mengajarkan nilai moral yang baik pada anak. Contohnya, sambil bercerita orangtua mengajarkan anak untuk berdo'a setiap sebelum dan sesudah makan, berterimakasih dan bersyukur dengan nikmat yang diterima, dan bersikap sopan santun kepada orang lain. Melalui cerita anak tanpa merasa diguruhi dan dinasehati dengan kata-kata yang menakutkan. Dengan demikian orangtua bisa mengajarkan dan menanamkan moral kepada anak sejak usia dini. Metode bercerita hendaknya menyesuaikan dengan kemampuan kognitif anak. Jadi cerita yang disampaikan haruslah menyesuaikan tingkat kemampuan kognitif anak (Muallifah, 2013).

Bercerita merupakan metode yang efektif dan paling banyak digemari pada usia anak. Alasannya: (1) cerita pada umumnya lebih berkesan dari pada metode lain. Bercerita mendorong anak-anak mengebangkan imaninasinya, karena pesan yang disampaikan dalam bentuk verbalisme yang mendorong anak-anak untuk berpikir, mengira-ngira dan menebak. Anak-anak diajak berpikir membayangkan sesuatu sehingga pada umumnya cerita terekam jauh lebih kuat dalam memori manusia; (2) melalui cerita anak diajarkan mengambil pesan, nilai dan hikmah. Bercerita akan membuat anak merasa lebih nyaman dari pada diceramahi dengan nasehat (Muallifah, 2013), dengan bercerita anak dapat membedakan tentang perilaku baik atau buruk, belajar tentang perjuangan dan kesetiakawanan (Rahman, 2013); (3) melalui cerita terjadi peningkatan kemampuan berbicara anak (Marini et al., 2015); (4) melalui cerita memiliki peran penting pada diri anak dalam pengembangan rasa empati (Kumoro, 2015).

Khoiruddin (2016) menyatakan Bercerita dan mendongeng memiliki banyak manfaat untuk anak. Seperti (1) memperkaya kosakata anak; (2) membangun kedekatan emosional antara pendidik dengan anak; (3) mendengarkan sebuah cerita dan dongeng bisa menstimulasi daya imajinasi dan berpikir agar anak tumbuh menjadi anak yang kreatif, melatih kemampuan mendengar; (4) usai membacakan dongeng, dilanjutkan dengan bertanya kepada anak mengenai cerita tersebut atau membiarkannya untuk bercerita ulang, hal ini bermanfaat untuk melatih daya ingatnya; (5) makin banyak anak mendengar, maka makin mudah anak untuk berbicara; (6) saat mendongeng, tertawa bersama dan bermanja-manja, hal itu bisa mempererat hubungan antara anak, sarana hiburan dan penarik perhatian; (7) media 
penyampai pesan/nilai mora dan agama yang efektif; (8) membantu proses peniruan perbuatan baik tokoh dalam cerita dan membangun watak mulia; dan (9) menggugah minat baca.

Nurgiyantoro (2010:217) menyatakan bahwa tingkah laku tokoh cerita anak haruslah dapat dijadikan teladan bagi pembaca anak-anak untuk bersikap, bertingkah laku, dan berinteraksi sosial dengan sesama dan lingkungan. Anak Sekolah Dasar kelas tinggi merupakan masa anak-anak akhir, usianya kira-kira 9 atau 10 hingga kisaran 12 atau 13 tahun. Pada masa ini, anak mengalami fase perubahan penting, yaitu berubahnya kehidupan fantasi yang subjektif menuju realisme objektif. Lambat laun, sikap subjektif yang diperoleh pada gambaran kehidupan nyata semakin objektif. Dapat dikatakan pada masa ini anak mengalami peralihan atau berada di antara fase operasional konkrit menuju fase operasional formal. Piaget menyatakan bahwa periode operasi tingkat berpikir konkrit dimulai dari usia 7-11 tahun, dan menuju peralihan tingkat berpikir formal dimulai dari usia 10-12 tahun (dalam Tarigan 2011:46). Apabila dikaitkan dengan sastra, pada periode ini anak sekolah dasar kelas tinggi cenderung menyukai fiksi dan realita. Melalui realitas kehidupan anak dari cerita anak yang diperdengarkan, anak diharapkan siswa dapat memperoleh gambaran kehidupan dari cerita anak. Di dalam karya sastra fiksi itu sendiri terdapat isi, yakni nilai- nilai kehidupan. Melalui nilai-nilai kehidupan, siswa diharapkan dapat mengeksplorasi isi cerita anak tersebut sesuai dengan perkembangan pengalaman personal. Siswa dapat memperkaya kehidupanya melalui pemecahan permasalahan dan masalah pribadinya. Proses pembelajaran dalam kerangka kompetensi abad 21 yaitu dari 21st Century Skills, Education, Competitiveness, Partnertship for 21 Century 2008 dinyatakan bahwa tidak cukup hanya meningkatkan pengetahuan saja, tetapi harus dilengkapi dengan kemampuan kreatif, kritis, berkarakter, kuat. Selain itu, proses pembelajaran didukung dengan kemampuan memanfaatkan informasi dan berkomunikasi (Kemdikbud, 2013:51).

Namun permasalahan terkait perangkat pembelajaran kurikulum 2013 dalam hal ini buku guru dan buku siswa masih ditemukan di lapangan. Temuan empiris menunjukkan bahwa terdapat beberapa persoalan dalam buku guru dan buku siswa tersebut. Beberapa kegiatan pembelajaran yang diarahkan dalam buku, masih kurang sesuai dengan karakteristik belajar anak. Menurut Piaget (dalam Marhaeni, 2013), anak usia SD yakni 6-12 tahun berada pada tahap operasional konkrit. Pada tahap ini anak dapat membuat pemikiran tentang situasi atau hal konkrit secara logis. Maka dari itu, karakteristik belajar anak pada tahap ini adalah belajar melalui hal-hal yang bersifat nyata dan menghindari cara belajar menghayal atau mengirangira. Namun, beberapa buku yang di temukan di lapangan tampak masih ada yang tidak menghadirkan situasi konkrit/nyata ke dalam pembelajaran. Sehingga muncul anggapan bahwa buku-buku tersebut tidak sepenuhnya relevan dengan karakteristik belajar anak usia SD.

Permasalahan lain yang ditemukan adalah konten uraian pembelajaran dalam buku kurang efisien dalam memuat nilai-nilai sikap dan muatan pembelajaran. Ditemukan beberapa konten pembelajaran yang kurang mampu mengoptimalkan penanaman nilai-nilai sikap kepada peserta didik. Selain itu, beberapa buku kurang mampu mengangkat muatan-muatan pembelajaran yang ada secara maksimal. Sehingga, sangat membatasi peserta didik untuk memeroleh ilmu pengetahuan apabila hanya mengandalkan buku tersebut.

Menurut Neina (2015) beberapa buku cerita anak yang beredar di pasar menunjukkan bahwa belum ada buku memproduksi cerita anak yang dapat dijadikan sebagai acuan belajar siswa. Setelah melihat karakter dan buku-buku cerita anak yang sudah ada, ditemukan bahwa buku cerita anak yang terintegrasi dengan CLIL belum ada. Buku-buku ini pun masih kalah jumlahnya dibandingkan dengan novel, cerpen, ataupun teenlit. Meskipun sudah ada buku yang khusus memuat cerita anak, buku tersebut belum dapat dijadikan sebagai sarana belajar karena hanya berisi kisah tanpa ada panduan untuk memahami nilai karakternya.

Selain itu, buku cerita anak yang beredar saat ini belum terintegrasi dengan ilmu lain, padahal cerita anak ini berpotensi untuk dijadikan sarana belajar dan penanaman nilai karakter. Adapun dan segi bahasanya, masih banyak pula dijumpai beberapa cerita anak yang menggunakan susunan kalirnat majemuk yang tidak sesuai dengan tingkat kognisi anak.

Ditemukan pula beberapa konten buku kurang yang mampu menggiatkan budaya literasi peserta didik. Padahal gerakan literasi sekolah (GLS) sedang giat- giatnya 
diberdayakan di Indonesia, mengingat rendahkan kemampuan literasi anak bangsa Indonesia. Berdasarkan data dari PIRLS dan PISA yang tersedia dalam www.pk-plk.com (2016), diketahui bahwa dalam PIRLS 2011 International Results in Reading, Indonesia menduduki peringkat ke-45 dari 48 negara peserta dengan skor 428 dari skor rata-rata 500. PISA 2012 menunjukkan peserta didik Indonesia berada pada peringkat ke-64 dengan skor 396 dari skor rata-rata OECD 496. Data PIRLS dan PISA, khususnya dalam keterampilan memahami bacaan, menunjukkan bahwa kompetensi peserta didik Indonesia tergolong rendah. Menurut Faizah, dkk (2016) secara umum tujuan dari gerakan literasi sekolah ini adalah untuk mengarahkan peserta didik menjadi pembelajar sepanjang hayat melalui pembudayaan ekosistem literasi. Untuk mewujudkan hal tersebut, tidak hanya diperlukan tindakan pembiasaan, tetapi juga sarana yang menunjang yakni buku sumber belajar. Dengan demikian, buku yang digunakan siswa sebagai sumber belajar hendaknya mampu merangsang minat literasi (membaca dan menulis) peserta didik.

Berdasarkan beberapa temuan empiris tersebut, dirasa perlu menyusun sebuah prototipe perangkat pembelajaran yang sesuai dengan kurikulum dan mampu membantu fungsi perangkat pembelajaran yang telah ada. Perangkat pemnbelajaran yang diduga tepat untuk dikembangkan adalah buku cerita anak. Buku cerita anak adalah buku yang memuat sastra anak yang berupa cerita/dongeng. Sastra anakadalah sastra yang mencerminkan perasaan dan pengalaman anak-anak masa kini, yang dapat dilihat dan dipahami melalui mata anakanak (Tarigan, 1995).

Buku cerita anak dipilih bukan tanpa sebab. Buku cerita anak lebih efisien dalam menanamkan nilai-nilai sikap kepada diri peserta didik. Penelitian yang dilakukan oleh Dr. Mona M. Farid pada tahun 2012 yang berjudul The effect of a story-based programme on developing moral values at the kindergarten stage, menemukan bahwa penggunaan cerita berpengaruh positif dalam pengembangan nilai moral anak. Diungkapkan bahwa "By guiding children to identify the moral value in a story, they will indirectly learn the moral lesson". Itu berarti, peserta didik akan langsung mengalami belajar tentang nilai-nilai melalui identifikasi nilai moral yang terkandung dalam cerita. Hal tersebut menandakan bahwa buku cerita anak efektif dalam mengajarkan dan menanamkan nilai-nilai sikap ke dalam diri anak/peserta didik. Selain itu menurut Tarigan (1995), buku cerita anak sangat bermanfaat untuk melatih daya pikir dan imajinasi anak. Ketika berhadapan dengan cerita/dongeng, anak akan memvisualisasikan cerita tersebut sesuai dengan imajinasinya. Maka dari itu, buku cerita anak dirasa efektif digunakan untuk mengajarkan muatan-muatan pembelajaran yang ada kepada siswa. Belajar menggunakan buku cerita anak juga lebih sesuai dengan karakteristik anak usia SD yang berada dalam tahap operasional konkret. Dalam cerita/dongeng, siswa akan berhadapan dengan suatu kisah yang dapat dihubungkan langsung dengan kehidupan atau pengalamannya di dunia nyata. Nilai-nilai dan materi pembelajaran dapat diungkap dengan memanfaatkan lakon, latar, atau jalan cerita yang ada di dalamnya. Dengan begitu, belajar akan lebih berkesan dan bermakna bagi siswa.

Buku cerita anak juga mampu merangsang minat literasi siswa secara tidak langsung. Penelitian yang dilakukan oleh Astawa, dkk (2015) tentang pengaruh pembelajaran inkuiri berbasis buku cerita terhadap minat baca dan hasil belajar membaca siswa menunjukkan bahwa, pembelajaran inkuiri berbasis buku cerita berpengaruh signifikan terhadap minat membaca dan kemampuan membaca siswa. Hasilnya pun positif dan lebih optimal dibandingkan dengan model konvensional.

Perlu diketahui bahwa, buku cerita anak dapat diangkat dari banyak sisi dan latar belakang. Namun, cerita yang dirasa baik untuk diangkat dalam prototipe buku cerita anak adalah cerita-cerita yang berasal dari budaya lokal. Budaya lokal merupakan sarana yang efektif dalam menanamkan nilai-nilai dan pengetahuan ke dalam diri peserta didik. Menurut Vygotsky dalam Mutiah (2010:103) "Anak menemukan pengetahuan dalam dunia sosialnya atau lingkungannya". Kebudayaan lokal yang terdiri dari kepercayaan-kepercayaan, nilai-nilai, pengetahuan-pengetahuan, hubungan yang terstruktur, sistem simbol bahasa lisan dan tulis sangat penting dalam pembelajaran sikap. Pemertahanan budaya lokal ditengah derasnya arus globalisasi merupakan salah satu hal yang penting dilaksanakan. Kecintaan siswa pada 
budaya lokal haruslah ditumbuhkan dari sejak dini, implikasinya dapat menumbuhkan rasa memiliki terhadap budaya lokal sehingga dapat dijadikan salah satu alat untuk menyaring dampak negatif globalisasi. Keragaman budaya yang melatarbelakangi masing-masing peserta didik menuntut guru agar memiliki wawasan yang luas terhadap keadaan sosial budaya yang ada pada lingkungan dimana guru mengajar. Pengetahuan guru tentang keragaman budaya yang dimiliki peserta didik, akan sangat membantu untuk keberhasilan pelaksanaan pendidikan. Keragaman budaya akan berpengaruh terhadap pola-pola sikap dan perilaku setiap individu. Adat istiadat, norma-norma dan kebiasaan-kebiasaan yang berlaku di masyarakat, satu dengan yang lainnya berbeda-beda.

Terlepas dari upaya yang dilakukan untuk menyiapkan kurikulum dan buku pelajaran, telah ditemukan satu sisi lain yang kemungkinan dapat mengganggu kesuksesan implementasi kurikulum 2013. Jadi diasumsikan bahwa apabila pembelajaran di kelas rendah berorientasi ekspositoris, maka ada kemungkinan terdapat kebosanan siswa dalam belajar karena siswa lebih menginginkan pendekatan naratif atau bercerita. Apabila kemungkinan itu terjadi, penyampaian materi tidak berjalan dengan baik. Berdasarkan asumsi itu juga menjadi sangat penting dengan adanya bahan pendamping seperti buku pelajaran yang bersifat naratif yaitu berupa buku cerita. Penelitian oleh Marhaeni, dkk (2017) juga telah mengajukan prototipe buku cerita yang dapat menjadi pendamping buku pelajaran. Prototipe tersebut baru sebatas isi buku cerita, adapun isi dari buku cerita itu dihasilkan dari hasil analisis terhadap muatan pelajaran pada tema-tema buku pelajaran kelas tinggi. Dengan demikian dikatakan bahwa prototipe tersebut sudah menyediakan buku cerita untuk setiap tema di kelas tinggi.

Isi prototipe ini tentu harus dikembangkan menjadi sebuah cerita yang dapat dinikmati oleh siswa. Menurut Sarumpaet (2003:111) unsur-unsur dalam membuat sebuah buku cerita anak yaitu unsur intrinsik dan ekstrinsik, unsur intrinsik meliputi tema, tokoh, latar, gaya bahasa, dan alur cerita. Sedangkan unsur ekstrinsik adalah unsur di luar aspek penulisan cerita. Unsur-unsur tersebut dipersiapkan terlebih dahulu sebelum membuat sebuah cerita anak. Unsur-unsur tersebut harus dipahami oleh pengarang agar hasil cerita berhasil dengan baik. Dengan kata lain unsur-unsur dalam cerita pendek sangat menentukan baik buruknya hasil cerita yang dihasilkan.

Selain itu dalam pembuatan buku cerita bermuatan kurikulum 2013 harus memperhatikan serta merumuskan KD dari pembelajaran yang akan dikembangkan. Butir-butir materi dan indikator juga disusun dan dirumuskan sedemikian rupa agar menghasilkan cerita yang saling berkaitan antar muatan pembelajaran. Dalam cerita anak penyusunan teks dan gambar harus seimbang karena disesuaikan dengan sasaran buku cerita tersebut yaitu siswa kelas V SD.

Untuk mengetahui efektifitas buku cerita yang dihasilkan, peneliti menggunakan model ADDIE (Analysis, Design, Development, Implementation, Evaluation). Tahap Analysis dan Design sudah dilakukan oleh penelitian sebelumnya dengan hasil berupa prototipe buku cerita anak. Sedangkan tahap Development, Implementation, dan Evaluation dilakukan pada penelitian ini. Ketiga tahapan tersebut bertujuan untuk mengembangan prototipe menjadi buku cerita, menguji hasil buku cerita kepada anak kelas 5 SD, dan menguji efektifitas buku cerita tersebut.

Dengan demikian agar hasil penelitian Marhaeni, dkk (2017) dapat digunakan maka harus dibuatkan buku cerita dari isi hasil penelitian tersebut dan buku cerita itu harus memenuhi unsur-unsur buku cerita anak yang baik seperti yang dikatakan oleh Sarumpaet (2003). Sejauh ini penelitian oleh Marhaeni, dkk (2017) belum ditindak lanjuti menjadi buku cerita. Oleh karena itu maka penelitian ini bertujuan mengembangkan buku cerita. Oleh karena itu penelitian ini diharapkan dapat mengembangkan buku cerita yang baik.

Berdasarkan uraian tersebut maka peneliti tertarik untuk mengkaji lebih jauh mengenai pengembangan media cerita anak sebagai media pembelajaran untuk membantu guru dalam mengemas suatu pembelajaran menjadi pembelajaran yang lebih menarik. Selain itu dalam media buku cerita peneliti dapat pula menyisipkan nilai-nilai karakter di dalamnya oleh karena itulah peneliti membuat sebuah media buku cerita pada tema "Lingkungan Sahabat Kita Subtema Manusia dan Lingkungannya". 


\section{Metode}

Jenis penelitian ini adalah penelitian pengembangan desain dan produk (Design and Development) dengan menggunakan Model ADDIE (Analysis, Design, Development, Implementatian, Evaluation). Tahapan penelitian Analysis dan Design telah dilaksanakan pada penelitian sebelumnya yaitu penelitian Lodo (2017) tentang analisis muatan sikap dan literasi dini pada buku pelajaran tema-tema SD kelas awal. Sedangkan tahapan penelitian ini adalah Development, Implementatian, dan Evaluation.

Untuk ketentuan subjek eksperimen atau sampel uji efektivitas buku cerita anak adalah ketentuan sampel kelas $\mathrm{V}$ sebanyak 26 orang siswa diambil dari populasi satu gugus SD di Kecamatan Buleleng. Subjek tersebut diambil menggunakan Porposive Sampling.

Dalam tahap Development, dilakukan perancangan buku cerita dengan mempertimbangkan aspek pembuatan buku cerita bergambar yang baik seperti yang telah dipaparkan di atas menurut Sarumpaet (2003). Dalam tahap ini, buku cerita diuji kualitasnya berdasarkan dimensi yang dikembangkan dari buku Gerakan Literasi Sekolah (2015). Kemudian, setelah buku cerita bergambar diuji kualitasnya, dilanjutkan dengan menyesuaikan isi buku cerita dengan pembelajaran subtema Manusia dan Lingkungan yang menginsersi budaya lokal Bali. Dimensi kesesuaian dikembangkan dari buku guru kelas $\mathrm{V}$ tema 8 , subtema 1. Pengujian tersebut dilakukan dengan bantuan 2 ahli. Dua ahli tersebut adalah dosen yang bernama Drs. I Gusti Nyoman Widnyana, M.Erg dan penulis cerita terkenal yang bernama Kadek Sonia Piscayanti, S.Pd., M.Pd mereka berkompeten dan ahli dalam pembuatan buku cerita anak, baik dari segi isi cerita, bahasa, gambar, dan pewarnaan gambar.

Pada tahap Implementation, Buku cerita yang sudah selesai dibuat dengan berdasarkan prototipe yang memerhatikan temuan-temuan dalam nilai-nilai sikap spiritual dan sosial, muatan pembelajaran dan muatan budaya lokal yang mendukung serta berkaitan dengan subtema Manusia dan Lingkungan kelas V SD, maka buku cerita tersebut sampai pada tahan implementation. Setelah mendapatkan masukan dari 2 ahli dan 2 guru, buku cerita tersebut dapat dicobakan sebagai buku pendamping buku pembelajaran Kurikulum 2013 di kelas V. Agar mempermudah guru menggunakan buku cerita dalam proses pembelajaran, maka nanti akan dibuatkan petunjuk penggunaan buku cerita yang terdapat langsung pada buku cerita tersebut.

Penelitian ini dilaksanakan di SD Negeri 2 Sukasada yang beralamat di Jalan Bukit Lempuyang, Kecamatan Sukasada, Kabupaten Buleleng, Provinsi Bali. Sekolah Dasar ini terdiri dari 6 kelas yang masing-masing terdiri dari \pm 25 siswa. SDN 2 Sukasada termasuk ke dalam sekolah dengan akreditasi $\mathrm{A}$. Kelas yang digunakan dalam penelitian ini adalah kelas $\mathrm{V}$. Jumlah siswa kelas $\mathrm{V}$ adalah 26 siswa.

\section{Hasil Dan Pembahasan}

Buku cerita ini dibuat berdasarkan prototipe yang telah dikembangkan pada penelitian sebelumnya pada tema Lingkungan Sahabat Kita. Untuk mempermudah pembuatan buku cerita yang berisi muatan sikap yang terdiri dari sikap spiritual dan sikap sosial, muatan pembelajaran, serta muatan budaya lokal yang mendukung, maka dipilih salah satu subtema yang ada pada tema Lingkungan Sahabat Kita, yaitu subtema Manusia dan Lingkungan.

Tahapan pertama pembuatan buku cerita dimulai dari penyusunan kerangka cerita anak. Kerangka cerita anak tersebut memperlihatkan tahapan pengembangan cerita yang terdiri dari 5 tahap yaitu: tahap membuka cerita, mengiring pada keasyikkan, pertengahan cerita, klimaks, sampai dengan menimba makna cerita. Kerangka cerita juga memperlihatkan secara rinci isi cerita, ilustrasi, halaman, muatan sikap, muatan pembelajaran dan muatan budaya lokal yang terkandung di dalam buku cerita.

Setelah kerangka cerita mendapat persetujuan, dilanjutkan dengan pembuatan cerita serta sketsa sesuai dengan ilustrasi. Sketsa dan cerita tersebut beberapa kali mengalami penyempurnaan. Pencetakkan buku cerita dilakukan setelah sketsa diwarnai dan jalan cerita disempurnakan. Tahap selanjutnya adalah mengetahui kualitas buku cerita tersebut. Hal ini 
dapat diketahui dengan membawa buku cerita kepada para ahli dalam bidang pembuatan buku cerita, serta kepada guru kelas $\mathrm{V}$ sebagai sosok yang memahami karakteristik siswa maupun pembelajaran di kelas V. Penilaian kualitas buku cerita dilakukan dengan menggunakan kuesioner yang diberikan kepada 2 ahli dan 2 guru. Dua ahli tersebut adalah Kadek Sonia Piscayanti, S.Pd.,M.Pd. sebagai ahli bahasa dan sastra dan Drs. I Gusti Nyoman Widnyana, M.Erg sebagai budayawan, serta 2 guru yaitu Made Suyasmini, S.Pd.,M.Pd dan Ni Ketut Yulianti S.Pd. sebagai guru yang memahami karakteristik maupun pembelajaran di kelas $\mathrm{V}$ sekolah dasar. berikut.

Adapun hasil perhitungan kuesioner kualitas buku cerita oleh ahli dapat dilihat sebagai

Tabel 1. Hasil kuesioner kualitas buku cerita

\begin{tabular}{llll}
\hline$M$ & Mi & SDi & Kategori \\
\hline 90,5 & 66 & 14,67 & Sangat Baik \\
\hline
\end{tabular}

Tabel 2. Hasil kuesioner kesesuaian buku cerita

\begin{tabular}{llll}
\hline $\mathrm{M}$ & $\mathrm{Mi}$ & SDi & Kategori \\
\hline 32 & 21 & 4,6 & Sangat Baik \\
\hline
\end{tabular}

Setelah mendapatkan masukan serta penilaian kuesioner, maka dilakukan penyempurnaan buku cerita disesuaikan dengan hasil penilaian kuesioner dan masukan dari para ahli tersebut. Penyempurnaan dilakukan dalam segala aspek, baik dari segi gambar, tulisan, maupun kalimat yang tercantum dalam buku cerita. Hal ini membuat buku cerita telah terlihat lebih menarik dari sebelumnya, sehingga buku cerita siap untuk digunakan sebagai pendamping buku pelajaran Kurikulum 2013.

Tahap Implementation

Pelaksanaan pembelajaran yang dilaksanakan oleh guru berjalan dengan lancar, baik, dan menyenangkan selama 6 hari. Satu hari dilaksanakan satu pembelajaran sesuai dengan buku guru, buku siswa Kurikulum 2013, dan skenario yang telah dibuat. Siswa terlihat antusias mengikuti kegiatan pembelajaran terutama saat menyanyikan lagu daerah serta mempraktikkan permainan mencongklak yang ada dalam buku cerita. Saat saat jam istirahat terlihat siswa membaca buku cerita tersebut bersama-sama. Siswa mendengarkan guru membacakan cerita tersebut. Siswa tertarik dengan isi dan gambar yang terdapat pada buku cerita. Guru dengan mudah mengaitkan cerita yang terdapat pada buku cerita dengan kegiatan pembelajaran. Guru mengajak siswa membandingkan sikap-sikap yang patut ditiru dan tidak, sesuai dengan isi cerita. Guru menekankan amanat yang terdapat dalam cerita kepada siswa. Pada akhir subtema Manusia dan Lingkungan siswa diberikan kuesioner minat baca, dan penilaian sikap siswa menggunakan lembar kuesioner yang diisi oleh siswa.

Efektivitas Penggunaan Buku Cerita "Pesona Pantaiku Pantai Lovina" Sebagai Pendamping Buku Pelajaran Kurikulum 2013 terhadap Sikap Siswa

Berdasarkan perhitungan, efektivitas penggunaan buku cerita terhadap sikap siswa sebesar 7,87 yang tergolong sangat efektif. Ini berarti, buku cerita "Pesona Pantaiku Pantai Lovina" efektif dalam meningkatkan sikap siswa baik pada sikap spiritual maupun sikap sosial. Hal tersebut terlihat dari pengamatan selama kegiatan pembelajaran dengan menggunakan buku cerita "Pesona Pantaiku Pantai Lovina" mendampingi buku Kurikulum 2013 siswa menunjukkan sikap-sikap positif seperti menghargai teman yang berbeda agama ketika berdoa. Teori tersebut didukung oleh hasil penelitian dari Walker (2017) mengungkapkan bahwa buku cerita sering digunakan sebagai alat pedagogis untuk menyampaikan pelajaran moral kepada anak-anak, untuk secara spontan memberikan "moral' sebuah cerita. Siswa berdoa menurut 
agamanya masing-masing sebelum kegiatan pembelajaran dimulai. Siswa bermain bersamasama saat istirahat tanpa membeda-bedakan agama. Mereka bahkan menunjukkan sikap berbagi dengan temannya baik berbagi makanan ataupun buku cerita, hal tersebut terlihat juga saat mereka membaca cerita "Pesona Pantaiku Pantai Lovina" bersama pada jam istirahat. Meskipun ada satu dua orang siswa yang masih bersikap mengganggu teman lainnya, namun berdasarkan pengamatan dan kuesioner yang dilakukan guru, secara keseluruhan siswa memiliki sikap yang baik setelah dibelajarkan menggunakan buku cerita.

Selain sikap spiritual tersebut, selama kegiatan pembelajaran, siswa menunjukkan sikap-sikap sosial yang seharusnya mereka miliki setelah mendapatkan pembelajaran subtema Manusia dan Lingkungan. Menurut Azwar (2009) menyatakan bahwa sikap sosial terbentuk dari adanya interaksi sosial yang dialami individu, sehingga dapat membentuk pola pikir yang dipengaruhi oleh pengalaman pribadi, kebudayaan, media masa, intitusi pendidikan, agama, serta faktor emosi dalam diri individu. Hal tersebut ditunjukkan dengan siswa yang dapat menyelesaikan tugas guru tepat waktu, melaksanakan kewajiban di kelasnya seperti piket, dapat menengahi teman yang sedang bertengkar atau saat berdiskusi kelompok. Sikap-sikap tersebut menunjukkan sikap siswa yang bertanggung jawab. Siswa selalu memberi salam "om swastyastu" kepada guru sebelum memulai pelajaran, saat bertemu di halaman sekolah, setelah jam istirahat, dan sebelum pulang sekolah. Mereka menunjukkan sikap menghormati pendapat temannya yang sedang maju di depan kelas. Sikap-sikap tersebut mencerminkan siswa memiliki sikap santun. Selanjutnya, sikap siswa yang menunjukkan peduli terlihat dari mereka membantu temannya yang sakit, terkena masalah atau bertengkar dengan teman lainnya di sekolah. Sampah yang berserekan akibat terkena angin yang kencang mereka langsung bersihkan. Sikap percaya diri ditunjukkan dari siswa yang berebut untuk maju ke depan kelas saat diminta oleh guru, siswa berani mengemukakan pendapat saat pelajaran berlangsung di kelas maupun dalam kegiatan diskusi kelompok, serta beberapa siswa dapat memberikan argumen yang kuat ketika mengemukakan pendapatnya.

\section{Efektivitas Penggunaan Buku Cerita "Pesona Pantaiku Pantai Lovina" terhadap Minat Baca Siswa}

Efektivitas penggunaan buku cerita terhadap minat baca siswa diperoleh sebesar 5,32 yang tergolong sangat efektif. Ini berarti, buku cerita "Pesona Pantaiku Pantai Lovina" efektif dalam meningkatkan minat siswa terhadap kegiatan membaca. Hal tersebut dapat dilihat dari raut wajah siswa yang sangat tertarik terhadap buku cerita "Pesona Pantaiku Pantai Lovina" saat pertama kali diperkenalkan oleh guru. Siswa menunjukkan antusias dan semangatnya dalam membaca buku tersebut bahkan saat istirahat. Saat membaca buku tersebut, siswa terlihat tersenyum dan mengomentari isi cerita dengan teman lainnya. Siswa tersebut juga menyanyikan lagu yang terdapat dalam cerita itu saat sedang membaca bahkan setelah mereka selesai membaca dan berjalan keluar kelas. Hal itu menunjukkan perasaan senang siswa terhadap membaca dan ketertarikannya terhadap buku cerita. Hal ini sesuai dengan hasil penelitian yang dilakukan oleh Ermadwicitawati (2013) bahwa siswa merasa terdorong menerapkan pendidikan karakter bangsa dalam kehidupan sehari-hari setelah membaca materi ajar cerita anak ini. Respons tersebut tidak terlepas dari materi cerita anak yang menstimulasi emosi siswa ketika membaca.

Beberapa siswa dapat menyimpulkan kegiatan yang terdapat dalam buku cerita ada kaitannya dengan pembelajaran yang sedang mereka dapatkan seperti bagian cerita Made yang menjaga lingkungan pantai. siswa mengatakan bahwa hal tersebut merupakan contoh pelestarian lingkungan dan menjaga lingkungan pantai tetap bersih. Saat guru meminta salah satu siswa untuk maju ke depan kelas, mereka berebut ingin membacakan cerita "Pesona Pantaiku Pantai Lovina" tersebut. Siswa pun senang pergi ke pojok baca maupun ke ruang perpustakaan untuk mencari berbagai sumber bacaan yang mereka sukai. Menurut Harris dan Sipay (dalam Sudiana, 2007:44) minat terhadap topik bacaan sangat berpengaruh terhadap pemahaman bacaan. Pada umumnya, pemahaman membaca seseorang akan lebih baik jika materi bacaan menarik baginya, hal ini berarti bahwa semakin tertarik terhadap topik bacaan, semakin tinggi pada kemampuan seseorang dalam mengingat informasi yang ada pada teks. 
Selain itu Santoso (2008) menyatakan bahwa Tumbuhnya minat baca akan menyebabkan kebiasaan membaca berkembang dan terjadinya peningkatkan keterampilan dalam membaca.

Menurut Anderson (dalam Widiyati, 2013) Keberhasilan belajar siswa dalam mengikuti proses kegiatan belajar mengajar di sekolah sangat ditentukan oleh penguasaan kemampuan membaca mereka. Siswa yang tidak mampu membaca dengan baik akan mengalami kesulitan dalam mengikuti kegiatan pembelajaran untuk semua mata pelajaran. Siswa akan mengalami kesulitan dalam menangkap dan memahami informasi yang disajikan dalam berbagai buku pelajaran, bukubuku bahan penunjang dan sumber-sumber belajar tertulis yang lain. Akibatnya, kemajuan belajarnya juga lamban jika dibandingkan dengan siswa-siswa yang tidak mengalami kesulitan dalam membaca. Kegiatan membaca melibatkan berbagai aspek, baik aspek berpikir, emosi, bahkan aspek minat. Minat memiliki pengaruh yang besar dalam membaca. Hasanah (dalam Widiyati, 2013) mengatakan bahwa minat baca menentukan tujuan membaca. Hal ini dapat dibenarkan karena seseorang yang memiliki hasrat yang kuat untuk membaca, tidak akan membaca tanpa alasan dan tujuan yang jelas. Minat baca juga menentukan frekuensi membaca. Seseorang yang memiliki minat baca yang tinggi, akan selalu membaca setiap ada kesempatan.

Minat baca berarti disposisi yang mendorong individu untuk mencari peluang dan sumber daya untuk melaksanakan kegiatan membaca. Ada dua cara untuk memeriksa minat seseorang dalam membaca. pertama seseorang tertarik kegiatan seperti membaca, sehingga ketika dihadapkan dengan buku, individu yang memiliki keinginan yang lebih besar, pengakuan dan mengingat mereka diarahkan pada kegiatan membaca. Kedua, pendekatan lain didasarkan pada isi atau objek yang menarik, bahwa minat stimulus materi untuk mempengaruhi kemampuan individu. Dalam pendekatan ini, lebih terfokus pada faktor-faktor situasional yang mempengaruhi minat baca. Misalnya, jenis bacaan, proses dan memori individu dalam membaca alam ekspositori, rangsangan visual seperti objek atau gambar yang dilihat, timulus pendengaran seperti pernah mendengar percakapan yang berbicara tentang membaca, atau kombinasi dari visual dan pendengaran seperti TV. (Hidi, 2001)

Dengan membaca maka membuka wawasan, meningkatkan pengetahuan dan keterampilan serta meningkatkan kreativitas sehingga anak semakin bergairah dan terpacu untuk belajar sehingga melalui aktivitas membaca diharapkan potensi anak semakin berkembang secara maksimal. Secara keseluruhan, buku yang banyak dibaca oleh siswa terdapat gambar yang menarik seperti buku cerita "Pesona Pantaiku Pantai Lovina".

\section{Simpulan dan Saran}

Berdasarkan pembahasan di atas maka dapat disimpulan bahwa buku cerita berjudul "Pesona Pantaiku Pantai Lovina" dikembangkan dimulai dari penyusunan kerangka cerita anak. Kerangka cerita anak tersebut memperlihatkan tahapan pengembangan cerita yang terdiri dari 5 tahap yaitu: tahap membuka cerita, mengiring pada keasyikkan, pertengahan cerita, klimaks, sampai dengan menimba makna cerita. Kerangka cerita juga memperlihatkan secara rinci isi cerita, ilustrasi, halaman, muatan sikap, muatan pembelajaran dan muatan budaya lokal yang terkandung di dalam buku cerita.

Kedua, dapat ditarik simpulan bahwa buku cerita berjudul "Pesona Pantaiku Pantai Lovina" efektif digunakan sebagai buku pendamping buku Kurikulum 2013 yang digunakan dalam proses pembelajaran di kelas V khususnya tema Lingkungan Sahabat Kita. Dikarenakan siswa mengalami perubahan ke arah yang lebih baik dalam sikap maupun hasil belajarnya.

Berdasarkan simpulan dan implikasi penelitian yang telah dipaparkan, maka dapat diajukan beberapa saran guna peningkatan kualitas pembelajaran dalam menerapkan kurikulum 2013 pada anak sekolah dasar. Bagi pendidik disarankan mampu meningkatkan serta memunculkan ide-ide kreatifnya khususnya dalam pembuatan buku cerita sebagai pendamping buku Kurikulum 2013.

Bagi siswa disarankan agar lebih meningkatkan perhatian minat dalam mendengarkan cerita anak guna menumbuhkan motivasi belajar yang akan membantu siswa dalam pengembangan sikap maupun hasil belajarnya. 
Mengingat keterbatasan waktu dan pokok bahasan yang digunakan dalam penelitian ini, maka disarankan kepada peneliti lain untuk melakukan penelitian lanjutan guna menyempurnakan buku cerita anak yang diajukan dalam penelitian ini, serta untuk penyempurnaan penelitian ini perlu pula dilakukan penelitian lanjutan untuk melakukan evaluasi dari penggunaan buku cerita, sehingga tujuan akhir dalam penelitian ini tercapai yaitu menghasilkan buku cerita anak yang akan difungsikan sebagai formula pelajaran pada tematema di kelas tinggi.

\section{Daftar Rujukan}

Astawa, dkk. 2015. "Pengaruh Pembelajaran Inkuiri Berbasis Buku Cerita Terhadap Minat Baca Dan Hasil Belajar Membaca Bahasa Indonesia Pada Siswa Kelas V Sd Gugus III Kecamatan Abang". E-Journal Program Pascasarjana Universitas Pendidikan Ganesha: Program Studi Pendidikan Dasar. Vol. 5 tahun 2015.

Daryanto. 2014. Pendekatan Pembelajaran Saintifik Kurikulum 2013. Yogayakarta: Penerbit Gava Media.

Ermadwicitawati, N. M. 2013. Pengembangan Materi Ajar Cerita Anak yang Mengandung Pendidikan Karakter Pada Pembelajaran Membaca Cerita Anak SMP Kelas VII di Singaraja. E-Journal Program Pascasarjana Universitas Pendidikan Ganesha: Program Studi Pendidikan Bahasa dan Sastra Indonesia (Volume 2 Tahun 2013).

Davis, RS. 1997. Comics: a Multidimensional Teaching in Integrated-Skill Classes. Nagoyama University: Japan. (Online) diakses 16 Juni 2018, (http://www.esllab. com /research/ comics.htm)

Faizah, U. 2009. Keefektifan Cerita Bergambar untuk Pendidikan Nilai dan Keterampilan Berbahasa Dalam Pembelajaran Bahasa Indonesia. Jurnal Cakrawala Pendidikan, November 2009, Th. XXVIII, No. 3

Harsubenowati. 2006. Pendidikan Karakter dan Pola Kepemimpinan dalam Meningkatkan Kualitas Pendidikan. Jurnal Pendidikan, 12 (1): 30-45. Tersedia http://isjd.pdii.lipi.go.id/ [diakses 12-5-2018].

Hidi, 2001. Interest, Reading, and Learning: Theoritical and Practical Consideration. Educ. Psychol. Rev. 13.

Kemendikbud. 2013. Implementasi Kurikulum 2013. Jakarta:Kementrian pendidikan dan Kebudayaan

Khoiruddin, A. Imam Taulabi, Ali Imron. 2016. Menumbuhkan Minat Baca Sejak Dini Di Taman Baca Masyarakat. Journal An-Nafs: Vol. 1 No. 2 Desember 2016.

Kumoro, I., 2015. Analisis urgensi metode pembelajaran bercerita bagi perkembangan empati anak di tk dharma wanita kendal tahun ajaran 2015/2016.

Lodo, N. S. A. 2017. Pengembangan Prototipe Buku Cerita Anak Berbasis Budaya Lokal Melalui Analisis Sikap dan Muatan Pembelajaran Tema Lingkungan Sehat Kita Kurikulum 2013 Kelas V Sekolah Dasar. Singaraja: Program Pasca Sarjana Universitas Pendidikan Ganesha.

Marhaeni, A. A. I. N. 2013. Landasan dan Inovasi Pembelajaran. Singaraja: Universitas Pendidikan Ganesha. 
Mitchell, D. 2003. Children's Literature an Imitation to the Word. Michigan State University.

Muallifah, 2013. Storytelling sebagai metode parenting untuk pengembangan kecerdasan anak usia dini. J. Psikoislamika 10.

Mutiah, D. 2010. Psikologi Bermain Anak Usia Dini. Jakarta: Kencana.

Neina, Q. A. Hari Bakti Mardikantoro, Teguh Supriyanto. 2015. Pengembangan Buku Pengayaan Menulis Cerita Anak Bermuatan Nilai Karakter Berdasarkan Content And Languange Integrated Learning (Clil) Untuk Siswa Sekolah Dasar Kelas Tinggi. Seloka 4 (2) (2015). Seloka: Jurnal Pendidikan Bahasa Dan Sastra Indonesia. Prodi Pendidikan Bahasa Dan Sastra Indonesia, Program Pascasarjana, Universitas Negeri Semarang, Indonesia.

Nurgiyantoro, B. 2010. Teori Pengkajian Fiksi. Yogyakarta: Gajah Mada University Press.

Sarumpaet, R. T., 2003. Struktur Bacaan Anak, dalam "Teknik Menulis Cerita Anak". Yogyakarta: Pink Books, Pusbuk, dan Taman Melati

Santoso, H. (2008). Membangun Minat Baca Anak Usia Dini Melalui Penyediaan Buku Bergambar. Jurnal Artikel Pustakawan Perpustakaan UM tahun 2011.

Tarigan, H.G. 1995. Menulis: Suatu Keterampilan Berbahasa. Bandung: Angkasa.

Widiyati, E. 2013. Peningkatan Minat Dan Kemampuan Membaca Permulaan Melalui Media Buku Cerita Binatang Dan Permainan Bahasa Siswa Kelas II SD Plus AI-Anwar Pacul Gowang Jombang. Jurnal Pendidikan Humaniora, Hal 405-413 Volume 1, Nomor 4, Desember 2013. Pendidikan Dasar Ips-Universitas Negeri Malang. 